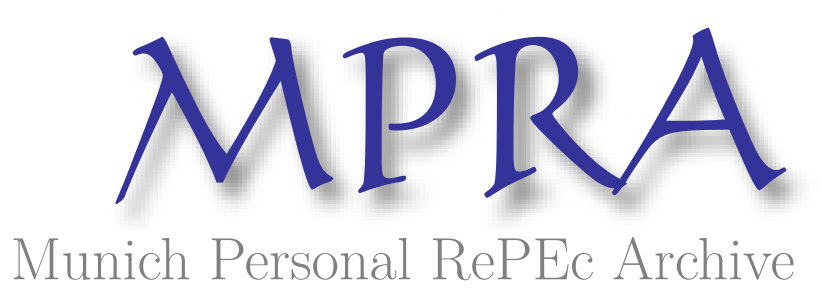

\title{
Corporate governance of banks: the current state of the debate.
}

Polo, Andrea

19 March 2007

Online at https://mpra.ub.uni-muenchen.de/2325/

MPRA Paper No. 2325, posted 20 Mar 2007 UTC 


\title{
CORPORATE GOVERNANCE OF BANKS: THE CURRENT STATE OF THE DEBATE
}

\author{
Andrea Polo*
}

January 2007

\begin{abstract}
Since banks are among the most important sources not only of finance but also of external governance for firms, the corporate governance of banks is a crucial factor for growth and development. Despite its importance, this topic has been explored only by a few studies. While some authors support, with different arguments in the course of time, the specificity of banks, other authors, among whom Ross Levine and his co-authors from the World Bank, question heavily the present banking regulatory framework. The debate on the corporate governance of banks has a direct bearing on the current discussions on the future of banking regulatory design: should the regulatory intervention be the most important corporate control mechanism in banking or should regulators focus on introducing incentives for appropriate market behaviour?
\end{abstract}

JEL Numbers: G18, G21, G28, G34, K22

Key words: Financial economics, Corporate Governance, Banking, Regulation and Supervision, Market Discipline, Securities Law

\footnotetext{
* University of Rome III and Collegio Universitario Federazione Nazionale Cavalieri del Lavoro, e-mail address: andreapolo@gmail.com. I am grateful to Ross Levine for his encouragement and guidance and Mario Sarcinelli for his very useful comments. I offer especial thanks to Paolo Santella for long and constructive conversations on the issues discussed here in. Remaining errors or inaccuracies are my own. This paper is available at www.ssrn.com.
} 


\section{Introduction.}

One of the most quoted definition of corporate governance is the one given by Shleifer and Vishny (1997): "Corporate governance deals with the ways in which suppliers of finance to corporations assure themselves of getting a return on their investment". The recent scandals and corporate failures in the United States and in Europe have led to a renewed interest in research of corporate governance. Scandals are simply manifestations of a number of structural reasons why corporate governance has become a central issue in the last two decades: the worldwide wave of privatization; pension fund reform and the growth of private savings; deregulation and the integration of capital markets (Becht, Bolton, and Röell 2003). In this new environment, the increased importance of the private, market-based investment process calls for a better corporate governance. The literature has underlined the impact of corporate governance on economic development. Claessens (2003) summarizes the channels through which corporate governance affects growth and development: increased access to external financing by firms, lower cost of capital and associated higher firm valuation, better operational performance through better allocation of resources and better management, reduced risk of financial crises, better relationships with all stakeholders.

Banks are themselves corporations. Corporate governace of banks affects banks'valuation, their cost of capital, their performance and their risk-taking behaviour. Formal econometric studies show that banks exert a strong impact on economic development (Levine 1997, 2005). When banks efficiently mobilize and allocate funds, this lowers the cost of capital to firms, boosts capital formation, and stimulates productivity growth (Levine 2004). Since banks exert corporate governance on firms, as creditors of firms and, in many countries, as equity holders, the corporate governance of banks becomes crucial for growth and development. Surprisingly enough, despite the importance of the topic, there are only a few studies on the corporate governance of banks. In the existing works, we find two contrasting views on this issue.: on the one hand, those who argue that the same core corporate control mechanisms that influence the governance of non-financial firms also influence bank operations and, on the other hand, the authors who state the specificity of banks.

The debate on the corporate governance of banks can be included among the more general attempt to answer the fateful question: are banks special?

In 1985 Eugene Fama wrote a famous article with the title: "What's different about banks?". This is still today a much debated question and the answer to this question has a strong impact on which financial regulation arrangement to choose.

Three different theories of financial intermediation have stressed the specificity of banks, even though for different reasons. We find, in chronological order, the classical theories ${ }^{1}$, the new view (Gurley and Shaw 1960, Tobin 1985), the theories based on asymmetric information (Diamond and Dybvig 1983, Diamond 1984). These theories focused on the three traditional roles of commercial banking: organisations of payment, maturity transformation and liquidity provision (Sarcinelli 2001). In contrast, the new financial intermediation theories (Allen and Santomero1996,1999, Allen and Gale 1997) describe all the financial intermediaries as risk managers, stressing similarities more then differences. Indeed financial and technology innovation, the spread of information (once the monopoly of the banker), the development of securitization techniques have caused a gradual declining in the traditional intermediation business. Now large banks earn their income more and more from fees and trading activities rather than from intermediation.

\footnotetext{
${ }^{1}$ For a comprehensive survey of these theories, see Santomero (1984)
} 
The purpose of this paper is to present the ongoing international debate on the corporate governance of banks and this will lead us to analyse, from this perspective, the current discussions on the future of banking regulatory framework.

The paper is organized as follows. Section 2 introduces the major governance concepts for firms in general, relying on Caprio and Levine (2002). Section 3 analyzes the way two special features of banks, opaqueness and regulation, reduce the effectiveness of the usual corporate governance mechanisms. In section 4 I report the debate on the "alleged" greater opacity of banks. In section 5, first, I reflect upon the rationales of bank regulation and, then, I report the empirical results, based on the first comprehensive cross-country data on how banks are regulated around the world, obtained by Professor Levine and his co-authors, whose findings seem to confirm that the same core corporate control mechanisms that influence the governance of non-financial firms can also influence bank operations. In section 6, I review further most recent arguments of the papers in favour of the specificity of banks. In section 7 I reflect upon the future direction of regulatory design. I conclude in section 8 .

\section{The corporate governance structure of a generic firm.}

The first papers which systematically study the corporate governance of banks are Caprio and Levine (2002) and Levine (2004). They review the major governance concepts for corporations in general and then discuss two special attributes of banks that make them special: greater opaqueness than other corporations and greater government regulation. They start defining the corporate governance problem in terms of how holders of equity and debt influence managers to act in the best interests of the providers of capital. Since large banks are one of the primary sources of corporate governance, it is essential that the managers of these institutions themselves face sound corporate governance. When this happens we have a better allocation of capital and a better corporate governance of firms in general ${ }^{2}$. Caprio and Levine, relying on Shleifer and Vishny's (1997) comprehensive review on the topic, start describing how small and large equity and debt holders exert corporate governance in a generic firm. They examine different mechanisms: diffuse shareholders, concentrated shareholders, diffuse debt holders, concentrated debt holders and the role of competition.

Diffuse shareholders may exert corporate governance directly through their voting rights (they vote on mergers, liquidation and fundamental changes in business strategy) and indirectly through the board of directors they elect. Moreover, executive directors compensation packages that link compensation with the achievement of particular results help align the interests of managers with those of shareholders. Nevertheless, the large informational asymmetries between managers and small shareholders, the lack of expertise of small shareholders to monitor managers, the "free-rider" problem, the possibility that the board does not represent the interests of the minority equityholders because it is captured by the management and controlling shareholders and, in some countries, legal systems that do not sufficiently protect the rights of shareholders, are all factors that keep these diffuse shareholders from exerting effective corporate control.

Concentrated shareholders can be a CG mechanism to avoid the conflict of interests between owners and managers. Large equityholders have the incentives to acquire information and monitor managers and they are able to avoid the managerial control of the board of directors. Here the problem consists in the possibility that large shareholders, instead of maximizing the

\footnotetext{
${ }^{2}$ On the importance of the corporate governace of banks in Europe, see Santella "Corporate governance bancaria, la madre di tutte le questioni”, www.lavoce.info, April 2006.
} 
value of the firm, act in order to maximize the private benefits of control exploiting small investors (Zingales 1994) through theft, transfer pricing, asset stripping.

The effective exertion of corporate monitoring by diffuse debtholders depends on the efficiency of the legal and bankruptcy system. Legal rights of debt holders should be clearly specified in debt contracts. In case of violations of debt covenants or default on the payments by the debtor, the debtholder should have the right to repossess collateral, to force the firm into bankruptcy and to vote on decisions about the assets of the firm. Very often, bankruptcy proceedings are inefficient, they take years to complete and repossession of assets is very difficult. All this, of course, reduces the power of diffuse debtholders to limit managerial discretion.

Large creditors, typically banks, find it easier to exert corporate governance. Banks can avoid the problem of inefficient bankruptcy proceedings by renegotiating the terms of their loans. Even in this case, the effective influence of large creditors over management relies on the legal and bankruptcy system: in any case, banks can renegotiate their loans but if the threat to throw the firm into bankruptcy is not credible, the renegotiation can be inefficient. Moreover, even when the influence of large debtholders is strong, this does not fully solve the corporate governance problem. Indeed, the interests of large creditors may not coincide with profit maximization, they can force managers to give up good investments and choose less risky projects because the creditors bear the potential cost, without sharing the potential upside gain.

Finally, two other forces give an important contribution to solve the corporate governance problem: product market competition and takeovers. As regards the first, in a competitive environment firms are forced to adopt corporate control mechanisms in order to minimize the cost of raising external finance. The second form of competition is takeovers: if a fluid takeover market exists, managers will have the incentives to maximize firm value in order not to be fired in a takeover.

The conclusion drawn by Caprio and Levine, is that there is some scope to improve the corporate governance of firms. Government intervention should be aimed at forcing firms to be more transparent, at increasing competition, both in product market and in takeovers, at protecting investors through a more efficient legal and bankruptcy system.

\section{Special features.}

After describing the corporate governance mechanisms for banks viewed as generic firms, Caprio and Levine go on to say that, owing to two special features: opaqueness and regulation, the corporate governance mechanisms in banks work less efficiently. In this section I report their arguments about the way these two features reduce the effectiveness of the mechanisms.

The greater opacity in banking makes it very difficult for diffuse debt and equity holders to monitor bank managers. It also makes it harder for debt holders to control banks from risk shifting: controlling owners have the incentive to increase the bank's risk profile, on the contrary, debt holders do not benefit from any upside potential from risk taking but do on the downside if the bank goes bankrupt. Moreover, the opacity of banks makes it more difficult to design contracts that align the interests of managers and shareholders and makes it easier for insiders to exploit outside investors. Finally, it reduces the two competitive forces: product 
market and takeover (the greater informational asymmetries between insiders and potential buyers and the long regulatory approval make takeovers rare in banking) ${ }^{3}$.

Levine (2004) analyses the adverse implications of government regulation for the corporate governance of banks. In the first place, most governments restrict the concentration of bank ownership and the ability of outsiders to purchase a substantial percentage of bank stock without regulatory approval and in some countries there may also be constraints on who can own banks (for instance, limits on ownership by nonbank firms). Yet, the very large percentage $(75 \%)$ of not widely-held banks and the fact that half of the controlling owners are families show that a paradox seems to operate: regulatory restrictions are not able to limit the family dominance of banks, but restrictions on purchasing equity actually defend the existing owners from competition for control, obstructing this source of corporate governance. Second, deposit insurance schemes reduce the incentives of depositors to monitor banks, induce banks to rely less on unsecured creditors and, along with the rise of central banks as lender of last resort, have contributed to create banks with low capital-asset ratio. Such factors have increased the incentives for bank owners to increase risk. Third, government interventions often restrict competition in output markets, hindering this corporate governance mechanism. Finally, when governments own banks the government is removed as an independent monitor, this weakens the incentives of private sectors to monitor and reduces overall competition.

\section{Opacity.}

Informational asymmetries between the providers of capital and the controllers of capital (managers) lie at the core of corporate governance problems. All firms suffer from some degree of information asymmetry between inside and outside investors. However, in most companies these problems are solved via market-based mechanisms (the financial market itself is able to give a price to financial activities thanks to disclosure provided by issuers). Financial firms, on the contrary, are subject to heavy government regulation whose rationale is based on the idea that bank assets are extremely difficult for outsiders to value and, consequently, market mechanisms cannot adequately control bank managers and shareholders. Although the conventional wisdom is that bank loans are informationally opaque and this has been justified on a variety of theoretical grounds (as seen above in section 2), some authors express doubts about it.

According to Flannery et al (2004):

"Loan illiquidity and private information about specific borrowers need not necessarily make banks more difficult to value than nonfinancial firms are. Just as many loans do not trade in active secondary markets, neither do many assets of nonfinancial firms: e.g., plant and equipment, patents, managers' human capital, or accounts receivable. How can outside investors accurately value the public securities issues by these firms?"

Empirically, bank opaqueness is not well established. As far as I know, there are three important papers which address the question of whether banks are relatively more opaque than other firms, with contradictory results. Morgan (2002) using data on U.S. bonds 1983-1993 and

\footnotetext{
${ }^{3}$ Adams and Mehran (2003) report four reasons why there have been very few hostile takeover bids: 1) state laws and banking regulation impose delays on hostile bids and this allows the target firms to arrange defences or seek alternative bids; 2) during the delay many stakeholder groups (competitors and consumers) can organize opposition and influence the decision of the regulator; 3) the medium of exchange in hostile takeovers is cash and the bidder typically borrows the funds needed for the acquisition. Yet, banks are unwilling to borrow funds for acquisition purpose as they are already highly leveraged; 4) the common presence of large block ownerships reduces the probability of success in a hostile offer.
} 
Iannotta (2004) using bonds issued by European firms during the 1993-2003 period find that rating agencies disagree more often over bank issues than over non-bank issues.

A different point of view is expressed by Flannery, Kwan and Nimalendran (2004) Using market microstructure properties and analyst's earnings forecasts, they find no evidence that banks are more opaque: bank stocks' trading behaviour suggests that they are not unusually difficult to value. They conclude that NYSE-traded banks (larger) do not differ significantly from their non-bank matched firms. Despite NASDAQ banks (smaller) trade significantly less often then comparable non-banks, yet analysts could predict their earnings as accurately as the latter, implying that smaller banks are even less opaque than their non-bank matches.

What kind of policy implication do the "supporters" of bank opacity argue from their studies? In concluding his paper Morgan says that "The push for increased market discipline and disclosure may shed light" and Iannotta reports that banks appear to be among the more opaque industries, but not the most opaque one and he goes on to say that part of bank uncertainty may be caused by the unclear, implicit government guarantees on bank liabilities. If government guarantees are vague, because they are extended beyond their de jure boundaries, market valuation of bank risk will be more subjective and less certain. Although bank risk is inherently hard to judge, there are some margins to increase bank transparency in order to enhance market discipline.

On the contrary, Flannery et al. conclude their paper by hypothesizing that special government supervision may somehow cause bank transparency. If banks are intrinsically more opaque, government supervisors have been extremely successful in reducing that opacity.

Summing up, state intervention seems to increase opacity (or even to cause it) on the one hand and to reduce it from the other. If a unique conclusion must be drawn, we might say that there is scope for government intervention to improve governance in banking by reducing bank opacity. Improving the flow of information through increased disclosure should enhance market discipline, in other words, it should foster the different potential bank monitors to do their job well. This is the rationale behind the third pillar of the New Basel Capital Accord .

\section{Regulation.}

Why are banks so heavily regulated? Two arguments are usually presented to justify bank regulation: systemic risk and depositor protection. Schemes of deposit insurance and the role of central banks as lenders of last resort are the main instruments governments have built to prevent bank runs, contagion, and other strains of "systemic" risk.

These instruments (which are commonly identified as "safety net") might lead to bank moral hazard, as it diminishes depositors' incentive to monitor banks and it increases banks' incentive to take more risks. Moral hazard comes up when gains accrue to decision-makers while losses are borne by other agents (heads I win; tails you lose). In our case moral hazard arises out of equity-holder/manager versus bondholder conflicts. It is a form of agency problem as the bondholders provide capital but do not control asset risk. The equity-holder appetite for risk derives from the observation first made in Black and Scholes (1972) that equity can be viewed as a call option on the value of the assets of the firm. There is a widespread belief that banks suffer from particularly severe moral hazard problems due to de facto too-big-to-fail policies and mispriced deposit insurance: bank equity holders have greater incentives to increase asset risk and thus expropriate bondholders (here the costs are born by taxpayers and the deposits insurer). ${ }^{4}$

\footnotetext{
${ }^{4}$ Yet, Bliss (2001) says that this argument is overly simplistic. He shows that more complex and realistic models of incentives lead to less clear-cut conclusions. The moral hazard analysis focuses solely on the incentives of equity-holder/managers to increase risk, implicitly assuming that the portfolio choices do not differ in their
} 
Moral hazard justifies capital regulation (requiring minimum capital as a percentage of riskadjusted assets, the I pillar of Basle II) and monitoring and supervision of banks' operations (II pillar). More in general, the highly regulated nature of banking empowers the regulatory authorities to influence, or even dominate, the corporate governance of banks. This has an impact on the incentives faced by private sector providers of bank corporate governance. Prowse (1997) has even argued that the most important corporate control mechanism in banking is regulatory intervention.

To sum up, in order to prevent systemic risk, governments have introduced "safety nets" made of central bank credit of last resort and deposit insurance schemes. However, the safety net approach produces perverse incentives on bank managers, shareholders and creditors, which explains the introduction of special minimum capital requirements for banks and in general the pervasive powers assigned to prudential regulators which may even constitute the main bank corporate control mechanism.

In the current debates on the future direction of regulatory design, some authors question the role and effectiveness of this rules-based bank regulatory oversight and underline the opportunity to enhance regulatory policy through private-sector solutions, for example market discipline (III pillar). Should the regulatory objective of preventing excessive risk-taking behaviour be pursued through externally imposed, prescriptive and detailed rules or could the regulator create incentives for appropriate behaviour, so that the same core corporate control mechanisms that influence the governance of non-financial firms could also influence bank operations?

Until recently, discussions on this topic could be based only on theory or anecdotal evidence because there were no comprehensive cross-country data on how banks are regulated. The first empirical work is provided by Barth, Caprio and Levine who created at the World Bank a detailed database on bank regulation and supervision in over 150 countries. In their book Rethinking Bank Regulation (2006), they conduct the first comprehensive assessment of the impact of bank regulatory and supervisory practices, examining the three pillars of Basel II. They find that empowering direct official supervision of banks and strengthening capital standards neither boost bank development nor improve bank efficiency, reduce corruption in lending, or lower banking system fragility. Their evidence suggests on the contrary that fortifying official supervisory oversight and disciplinary powers impedes the efficient operations of banks, increase corruption in lending and hurts the effectiveness of capital allocation (although the negative impact vanishes when countries have extremely open, competitive, democratic political institutions). In contrast, bank supervisory and regulatory policies that facilitate private sector monitoring of banks, for example forcing banks to disclose accurate information to the public (III pillar), improve bank operations, bank efficiency and reduce corruption in lending.

They reject the technical approach (measuring capital, defining non-performing loans, etc) and place banking regulation and supervision within a broader political economy context. The operation of banks is influenced by the political, cultural, legal environment and a sequence of

expected returns. This is unlikely to be the case. Where equity holders are not the managers, and agency problems are significant, equity holders and bondholders will have the same interests as regulators in higher expected asset returns, holding risk constant. Agency problems in the form of poor managerial decision- making (fraud, selfdealing, lack of internal controls, inadequate/incompetent credit screening, and overpaying for acquisitions) are a potentially important alternative cause of banks getting into trouble, that moral hazard is not the only problem. 
agency problems are involved, between public and politicians, politicians and supervisors, supervisors and banks, banks and counterparties, when regulation is not exclusively focused on market instruments. This complex system of multiple agency problems is further complicated by possible corruption. Since regulation and supervision of banks influence who gets to use society's savings, powerful individuals will try to influence politicians and supervisors in order to promote their own interests. "Popular approaches to bank supervision assume either that bank supervisors and politicians naturally behave like angels or that sufficient institutional mechanisms exist to ensure such behaviour".

Two other more recent empirical papers which use the same approach give answers to the two questions we have been dealing with throughout this paper. First, is it true that corporate governance mechanisms which apply to firms in general are not equally valid in banking? Does this justifies the regulatory authorities to influence, or even dominate, the corporate governance of banks in place of private monitors? Second, is the second set of intrusive and heavy regulatory measures (I and II pillars of Basle 2) really necessary to reduce the incentives to excessive risk-taking created by the first layer of regulatory measures (safety net)? Would market discipline and other clearly-defined rules produce the same results (or even better)?

Caprio, Laeven, Levine (2006), using a database on the ownership of 244 banks in 44 countries, analyse which laws and regulations enhance the corporate governance of banks. La Porta et al. (2002) find evidence of higher valuation of firms in countries with better protection of minority shareholders. In general, investor protection laws seem to prevent large shareholders from expropriating minority shareholders. Does this work in banking too? As seen above, many authors say no: banks are opaque and it is inefficient for small shareholders to monitor and govern complex banks, even with strong shareholder protection. In addition, banking regulation and supervision may render this laws superfluous. In contrast, Caprio et al. show that bank valuation is influenced by shareholder protection and ownership structure as nonbank firms: larger cash-flow rights by the controlling owner boosts valuations ${ }^{5}$ and weak shareholder protection laws lower bank valuations. Furthermore they do not find evidence that the stringency of capital requirements (pillar I), official supervisory power (pillar II) or regulatory restrictions on bank activities influence the market valuation of banks, reducing the fear of expropriation.

The empirical results of Laeven, Levine (2006) are even more striking. This is the first simultaneous study of the impact of a bank's private governance arrangements and national policies, along with potential interactions between the two, on bank risk taking. They find that banks that have large owners with substantial cash flow rights are characterised by higher bank risk than widely-held, managerially-controlled banks, as it was to be expected within the core theories of the firm. However, they show that the first two pillars of Basle 2 do not reduce bank risk taking. Moreover, indicators of prompt corrective action policies and loan provisioning stringency requirements do not account for cross-bank differences in risk taking. Put it differently, prudential regulation of banks does not seem to play any beneficial effect. Their paper constitutes a further empirical support to the evidence provided in Barth, Caprio and Levine (2006), who find that these two pillars of Basle 2 neither promote bank stability nor bank efficiency. Furthermore, not only do not these two pillars have any positive effects but also powerful supervisory agencies tend to increase corruption in lending (Beck et al. 2007). Laeven and Levine find also that regulation focused on allowing firms to engage in non-

\footnotetext{
${ }^{5}$ As the cash-flow rights of the controlling shareholders increase, their incentives to expropriate resources from the corporation decrease as expropriation involves reduction in their own cash flow.
} 
lending activities, in countries with active securities markets, or encouraging banks to hold diversified loan portfolios do reduce bank risk.

One potential limitation faced by their analysis regards the way one of the variable they use in their regressions is built. The variable is RIGHTS, the La Porta, et al. (2002) index of the legal protection of shareholders across countries. This index ranges from zero to six, where larger values indicate greater legal protection of shareholder rights. Spamann (2006) states that the LLSV (1998) Antidirector Rights Index (ADRI) is unlikely to be a valid measure of shareholder protection, he re-codes the Index and shows that non-recoded ADRI was systematically incorrectly measured. Spamann says that "the numerous empirical studies of the last 10 years that have used the non-recoded ADRI as a measure of investor protection may have obtained erroneous results, and may have to be revisited".

\section{Further arguments pro specificity of banks corporate governance.}

Those authors who in the most recent debate underline the uniqueness of bank corporate governance focus their attention on two main aspects: the necessity of an expanded set of fiduciary duties for bank directors and the empirical differences in the corporate governance relevant variables between banking and manufacturing firms, above all CEO compensation.

Macey and O'Hara (2003) state the first argument. They begin their analysis with the difference between the Anglo-American and Franco-German model of corporate governance: in the first approach the exclusive focus of corporate governance should be shareholder value maximization, by contrast, in the Franco-German model the interests of stakeholders, particularly banks and employee groups, have the same degree of respect as those of shareholders. In the American corporate governance the legal manifestations of the commitment of managers and directors to maximize shareholder value are the fiduciary duties of care and loyalty that managers and directors they owe to shareholders. According to the authors, the scope of the duties and obligations of corporate officers should be expanded in the special case of banks to ensure the safety and soundness of these firms. This "speciality" lays on the two unique features of banks: the liquidity production role and a stronger conflict of interest between shareholders and creditors (moral hazard as described above), because of a higher leverage compared to nonbank firms and the presence of deposit insurance schemes. For these reasons, they "support a hybrid approach to corporate governance in which most firms are governed according to the U.S. model, while banks are governed according to a variant of the Franco-German paradigm". Bank directors should expand the scope of their fiduciary duties beyond equityholders to include creditors. Therefore, they should take solvency risk explicitly and systematically into account when taking decisions, or else face personal liabilities for not doing so.

The uniqueness of bank corporate governance is stated also in Adams and Mehran (2003). They conclude for an industry-specific approach to corporate governance because of the systematic differences they find in corporate governance relevant variables between banking and manufacturing firms. Their sample consists of thirty-five bank holding companies (BHCs) over the 1986-96 period. From their comparison they obtain the following findings. On average, banks have a bigger board size, larger percentage of board directors, more committees and meet slightly more frequently. Moreover, measured in percentage terms, the ratio of chief executives' stock option pay to salary plus bonuses and the percentage of CEO direct equity holdings are smaller at banks. The authors suggest that "these differences are due to the differences in the investment opportunities of BHCs and manufacturing firms as well as to the 
presence of regulation". Apart from the objections one could raise on the results of the paper (the sample is small and quite old and if the group of manufacturing firms were split, there would still probably be systematic differences for different industries), the information about CEO compensation packages is of particular relevance in comparison with the other variables. Both Adams and Meheran (2003) and John and Quian (2003) affirm that, although in nonfinancial firms stock options may be appropriate instruments to provide incentives for managers to create value (as noted in section 2, Ceo compensation packages that link compensation with the achievement of particular results help aligning the interests of managers with those of shareholders), in banking stock options may conflict with policy objectives that seek to protect the nonshareholding stakeholders, such as depositors and taxpayers in financial firms. Put it differently, stock options are not good in banks because they increase too much the incentives for managers to invest in riskier assets. The lower reliance on stock options in the banking industry that Adams and Mehran empirically find (this is consistent with the results found by Houston and James 1995) is due, according to the authors themselves, to the fact that boards can observe, monitor, and evaluate the actions of CEOs in banks much easier than they can in other industries (weren't banks supposed to be more opaque than other firms?!) because banking firms are characterized by low-growth opportunities (measured by Tobin's-Q and Market-to-book ratio) and low volatility (standard deviation of monthly and daily returns). They also report another argument: the incentive for risk-taking is anticipated by debtholders, and thus increased reliance on stock options gives rise to a debt premium, or cost of debt. The size of the premium is related to the leverage ratio. To reduce the cost of debt, such leveraged firms as banks may choose to scale back their use of stock options. John and Qian (2003) support this argument, finding that the lower the pay-performance sensitivity for CEOs of BHCs is, the higher the ratio of the BHCs' debt to total assets is.

Even accepting such conclusions (the minor reliance on stock options in banking), this cannot be an argument in favour of the thesis of the specificity of banks and the consequent quest for regulation, because the market itself seems to solve the problem asking for a CEO compensation which is coherent to the particular industry characteristics. In fact, John, Saunders, and Senbet (2000) argue that regulation that accounts for the incentives of top management will be more effective than capital regulation in ameliorating risk-shifting incentives.

Adams and Meheran conclude suggesting that future research should examine the effect of governance structures in banking on measures of firm performance and on the incentives for risk-taking. This is exactly the work done by Ross Levine and his co-authors in the two papers presented above, respectively "Governance and bank valuation" and "Corporate governance, valuation and bank risk taking", whose findings, as we noticed, reach opposite conclusions.

\section{An increasing role for market discipline}

In the light of the discussions above and taking into account an increased difficulty by supervisors to monitor in a timely manner large and complex banking organizations, supervisors have started to rely on market mechanisms to supplement their traditional supervisory methods.

One of the differences between the Basel Capital Accord (1988) and the New Basel Capital Accord (2004) is the introduction of market discipline as one of the three pillars on which financial regulation is based. (we remind that the other two pillars are minimum capital standards and supervisory review of capital adequacy). This third pillar focuses on regulation 
that require accurate information disclosure and facilitate market oversight and discipline of banks.

The awareness of the importance of market discipline for a sound financial system by the banking regulatory community is evident, also, in the Core Principles for Effective Banking Supervision published by the Basel Committee on Banking Supervision (1997): "Supervisors should encourage and pursue market discipline by encouraging good corporate governance and enhancing market transparency and surveillance" (p.8). Again on page 9 it suggests "Supervision cannot, and should not, provide an assurance that banks will not fail. In a market economy failures are part of risk taking." and on page 12, "Effective market discipline depends on an adequate flow of information to market participants, appropriate financial incentives to reward well-managed institutions and arrangements that ensure that investors are not insulated from the consequences of their decisions", (Mayes 2000).

Market discipline, according to Lane's seminal work (1993), is "financial markets providing signals that lead borrowers (in this case banks) to behave in a manner consistent with their solvency". Three classes of private bank-stakeholders: depositors, debtholders and equityholders can signal market discipline. Depositors can either demand a higher return or withdraw their deposits if the bank risk increases. Similarly, debt-holders can demand a higher yield on bank debt, thereby increasing the cost of funds for riskier institutions and equityholders can sell their shares, putting pressure on share prices and placing management under increased scrutiny. For this to happen, investors must consider themselves at risk in the event of default and must be able to effectively observe bank risk thanks to reliable and timely information disclosure (Hamalainen, Hall and Howcroft 2005).

So market discipline and a good corporate governance play the role of restraining bank risk taking, objective that regulators and supervisors have been trying to pursue through prudential regulation. Laurence $\mathrm{H}$. Meyer, as member of the Board of Governors of the Federal Reserve System, in an official speech expressed this point with the following words:

We have often said that we want supervision and regulation to simulate or mimic market discipline in the sense of creating the proper incentives, costs, and rewards. I also believe that we ought--where we can--to skip the middlemen and go right to our first line of defence: market discipline. By aligning market incentives with regulatory incentives, policies designed to harness market forces could complement bank supervision by encouraging banks to refrain from excessive risk-taking. ${ }^{6}$

The fact that prudential regulation and market discipline are two different instruments for the same objective and the criticisms against the efficacy and efficiency of the current rules-based bank regulatory oversight lead some authors to propose to rebalance the three pillars of Basle 2 (a few figures express clearly this imbalance: 132 pages are used to describe pillar I, 16 pages for pillar 2 and 15 pages for pillar 3). Rochet (2004) develops the first formal model of banking regulation that permits analysis of the interactions between the three pillars. He shows that mandatory subdebt ${ }^{7}$ (direct market discipline) may, under some restrictions, allow regulators to decrease capital requirements and that market discipline and supervisory action are complementary rather than substitutes. Moreover, empirical work provided by DemirgüçKunt, Detragiache and Tressel (2006) on the relationship between compliance with the Basel Core Principles for Effective Banking Supervision (BCPs) and bank soundness, shows that the

\footnotetext{
6 "Market Discipline as a Complement to Bank Supervision and Regulation", Remarks by Governor Laurence H. Meyer Before the Conference on Reforming Bank Capital Standards, Council on Foreign Relations, New York June 14, 1999, www.federalreserve.gov/boardDocs/Speeches/1999/19990614.htm.

${ }^{7}$ See footnote 9 .
} 
principles related to information provision have the strongest impact on bank soundness. For this reason, the authors suggest that countries aiming to upgrade banking regulation and supervision should consider giving priority to information provision over other elements of the Core Principles. This is consistent with the approach to regulation and supervision recommended by Barth, Caprio, and Levine (2006), who stress the importance of mechanisms able to empower market discipline.

Yet, the availability of adequate information (which represents the objective of the third pillar of Basle II and needs to be further developed) is certainly a necessary condition for markets to operate effectively but it is not a sufficient criterion on its own. In a more market-based approach, the challenge of banking regulation and supervision should be the improvement (or creation) of all the conditions required for market discipline to work at its best:

- market participants must not believe that banks would be bailed out in the case of an actual or impending default;

- coverage limits should be set for deposit insurance: only very small depositors should be protected, on the opposite, large depositors, subordinated debtholders and correspondent banks must be convinced that their funds are truly and inescapably at risk $^{8}$

- directors and managers need to be held legally accountable in the event of fraud or failure, penalties should be imposed on the individual directors who have signed false disclosure statement (of course, penalties must not be so harsh that they deter reputable people from becoming bank directors);

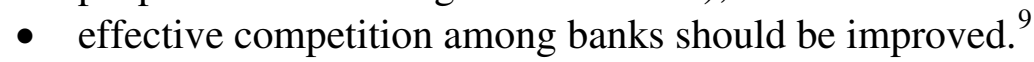

\section{Conclusions.}

This paper presented the current debate on the corporate governance of banks. On the basis of the existing works we find two conflicting views.

On the one hand, some authors state the specificity of banks: the common mechanisms of corporate governance, which are valid for firms in general, are not equally valid in banking and this legitimates the regulatory authorities to influence, or even dominate, the corporate governance of banks in place of private monitors. They justify this on a variety of different grounds in the course of time. The traditional argument is the grater opacity of banks: bank assets are extremely difficult for outsiders to value and, consequently, market mechanisms cannot adequately control bank managers and shareholders. Today, the authors who underline the uniqueness of banks seem to have switched their attention to such different aspects as the need for an expanded set of fiduciary duties for bank directors and the empirical differences in the governance-relevant variables between banking and manufacturing firms.

\footnotetext{
${ }^{8}$ For a a set of principles of good design based on crosscountry empirical work, as well as individual country experiences, see Demirgüç-Kunt, Kane, Laeven (2006).

9 Another potential beneficial tool to increase the market discipline of banks could be the mandatory subordinated debt proposals. The idea is to create a significantly large class of financially sophisticated and uninsured investors who will be subject to loss if a bank becomes insolvent. These investors, therefore, would have a substantial financial incentive to monitor, accurately assess and price bank risk. For an overview of these proposals see Bliss (2001)
} 
On the other hand, Levine and his co-authors from the World Bank, on the basis of the first empirical works on the topic, affirm that the same core corporate control mechanisms that influence the governance of non-financial firms also influence bank operations: bank valuation is, indeed, influenced by shareholder protection and ownership structure as nonbank firms. Prudential regulation, on the opposite, does not seem to have any impact either on market valuation of banks or on their risk taking behaviour. The regulatory goal of preventing excessive risk-taking should be better pursued through the introduction of incentives for appropriate behaviour by bank shareholders, debtholders and depositors. Government intervention can reduce the opacity of banks, thus fostering the private ability to assess and price bank risk, by improving the flow of information through increased disclosure requirements. This means that a stronger importance should be posed by the regulatory authorities on the third pillar of Basle 2, which today is the least developed one (15 pages for pillar III, 132 pages for pillar I).

In the light of the empirical results of this last group of authors and in spite of the possible limitations of their analysis (Spamann 2006), in the near future, the multilateral regulatory debate might consider whether and to what extent there is scope for any banking regulation which does not rely on pure market mechanisms. 


\section{References.}

Adams, R. and H. Mehran, (2003), "Is Corporate Governance Different for Bank Holding Companies?” FRBNY Economic Policy Review 9(1), 123-142.

Allen F. e D. Gale (1997) : "Innovations in financial services, relationships and risk sharing”, Wharton Financial Institutions Center.

Allen F. e A. M. Santomero (1996) : "The theory of financial intermediation", Wharton Financial Institutions Center.

Allen F. e A. M. Santomero (1999) : "What do financial intermediaries do?", Wharton Financial Institutions Center.

Barth, J. R., G. Caprio, and R. Levine, (2006), Rethinking Bank Regulation: Till Angels Govern. New York: Cambridge University Press.

Becht, M., Bolton, P and Röell, A., (2002) "Corporate Governance and Control". ECGI Finance Working Paper No. 02/2002

Beck, T., A. Demirguc-Kunt and R. Levine, (2007), "Bank Supervision and Corruption in Lending," Journal of Monetary Economics, forthcoming.

Black, F., and M. Scholes, (1972), "The valuation of option contracts and a test of market efficiency”, Journal of Finance, Vol. 27, No. 2, May, pp. 399.417.

Bliss, R.R. (2001), "Market Discipline and Subordinated Debt: A Review of Some Salient Issues", Economic Perspectives, Federal Reserve Bank of Chicago, 1, 24-45.

Caprio, G, Laeven, L and R. Levine (2006). "Governance and Bank Valuation", http://www.econ.brown.edu/fac/Ross_Levine/Publication/Forthcoming/Forth_GC-LL-

RL_Govn\%20\&\%20Valuation.pdf

Caprio, G., Levine, R., (2002). "Corporate governance in finance: Concepts and international observations", In: Litan, R.E., Pomerleano, M., Sundararajan, V. (Eds.), Financial Sector Governance: The Roles of the Public and Private Sectors. Washington, DC: Brookings Institution Press, pp. 17-50.

Claessens, S., (2003) "Corporate Governance and Development". Available at SSRN: http://ssrn.com/abstract $=642721$

Demirguc-Kunt, A. , Detragiache, E. and Tressel, T., (2006), "Banking on the Principles: Compliance with Basel Core Principles and Bank Soundness". World Bank Policy Research Working Paper No. 3954

Demirguc-Kunt, Asli , Kane, Edward J. and Laeven, Luc A., (2006), "Deposit Insurance Design and Implementation: Policy Lessons from Research and Practice". World Bank Policy Research Working Paper No. 3969

Diamond D. e P. Dybvig (1983) : "Bank runs, deposit insurance and liquidity", Journal of Political Economy 
Diamond D. (1984) : "Financial intermediation and delegated monitoring", in Review of Economic Studies.

Fama E. (1985): “What's different about banks?”, Journal of Monetary Economics

Flannery , M. J., Kwan, S. and Nimalendran, M., (2001), "Market Evidence on the Opaqueness of Banking Firms' Assets". Eleventh Annual Utah Winter Conference.

Gurley J. e E. Shaw (1960) : "Money in a theory of finance", Washington, Brooking Institutions.

Hamalainen, P., Hall, M.J.B. and Howcroft J. B., (2005), "A Framework for Market Discipline in Bank Regulatory Design" . Journal of Business Finance \& Accounting, Vol. 32, No. 1-2, pp. 183-209.

Houston, J., and C. James. (1995). "CEO Compensation and Bank Risk:Is Compensation in Banking Structured to Promote Risk Taking?’Journal of Monetary Economics 36: 405-31.

Iannotta, G., (2004), "Testing for Opaqueness in the European Banking Industry: Evidence from Bond Credit Ratings". SDA Bocconi Working Paper No. 122/04

John, K. and Y. Qian, (2003), "Incentive Features in CEO Compensation in the Banking Industry,” FRBNY Economic Policy Review 9(1), 109-121.

John, K., A. Saunders, and L. W. Senbet. (2000). "A Theory of Banking Regulation and Management Compensation.” Review of Financial Studies 13, no. 1: 95-125.

Laeven, L. and R. Levine (2006). "Corporate Governance, Regulation, and Bank Risk Taking", http://www.econ.brown.edu/fac/Ross_Levine/Publication/Forthcoming/bank_stability_RFS.pd $\underline{f}$

Lane, T. D. ,(1993), “Market Discipline”, IMF Staff Papers, 40, 53-88.

La Porta, R., F. Lopez-de-Silanes, A. Shleifer, and R. Vishny, (2002), "Investor Protection and Corporate Valuation," Journal of Finance 57, 1147-1170.

Levine, R., (1997), "Financial development and economic growth: Views and agenda", Journal of Economic Literature 35, 688-726.

Levine, R. (2004). "The Corporate Governance of Banks: A Concise Discussion of Concepts and Issues." in Global Corporate Governance Forum Washington, D.C. (www.gcgf.org) and The Certified Accountant, 18, April.

Levine, R, (2005), "Finance and Growth: Theory and Evidence", in Handbook of Economic Growth. Eds. Philippe Aghion and Steven Durlauf, Amsterdam: North- Holland Elsevier Publishers.

Macey, J. and M. O'Hara, (2003), “The Corporate Governance of Banks," FRBNY Economic Policy Review 9(1), 91-107.

Masera R., (2006), La corporate governance nelle banche, Il Mulino, Bologna. 
Mayes, D. G., (2000). "A More Market Based Approach to Maintaining Systematic Stability". Financial Services Authority Occasional Paper Series No. 10.

Morgan, D., (2002). "Rating banks: Risk and uncertainty in an opaque industry". American Economic Review 92, 874-888.

Prowse, Stephen, (1997), "The Corporate Governance System in Banking: What Do We Know?" Banca del Lavoro Quarterly Review (March), 11-40.

Rochet, J.C., (2004), "Rebalancing the Three Pillars of Basel II" . Economic Policy Review, Vol. 10, No. 2.

Santella P., (2006), "Corporate governance bancaria, la madre di tutte le questioni", www.lavoce.info, April.

Santomero A. M. (1984) : "Modeling the banking firm: a survey", Journal of money, credit and banking.

Sarcinelli M. (2001) :"State Aids in Rescuing and Restructuring Operations: Should banks be treated differently from other businesses?", European Competition Law Annual 1999: Selected issues in the field of State aids, Claus Dieter Ehlermann \& Michelle Everson, The Robert Schuman Centre, European University Institute, Hart Publishing, Oxford - Portland Oregon, 2001, pp. 305-22.

Shleifer, A., Vishny, R.W., (1997), “A survey of corporate governance”, Journal of Finance 52, 737-783

Spamann, H., (2006), "On the Insignificance and/or Endogeneity of La Porta et al.'s 'AntiDirector Rights Index' under Consistent Coding". Harvard Law School John M. Olin Center Discussion Paper No. 7

Tobin J. (1985) : "Financial innovation and deregulation in perspective", Bank of Japan monetary and economic studies.

Zingales, L., (1994), "The value of the voting right: A study of the Milan stock exchange experience", Review of Financial Economics 7, 125-48. 